\title{
Prescription of antibiotics as a source of emerging antibiotic resistance: Knowledge, attitudes, and practices of medical staff in the Dassa-Glazoué and Savalou-Bantè's health zones (Benin, West Africa)
}

\author{
Victorien Dougnon ${ }^{1}$, Yossounon Chabi ${ }^{2}$, Hornel Koudokpon ${ }^{1}$, Jerrold Agbankpe ${ }^{1}$, Richard Sefounon ${ }^{1}$, \\ Didier Alle ${ }^{1}$, Honoré Bankole ${ }^{1}$ and Lamine Baba-Moussa ${ }^{3}$
}

\begin{abstract}
1. Research Unit in Applied Microbiology and Pharmacology of natural substances, Research Laboratory in Applied Biology, Polytechnic School of Abomey-Calavi, University of Abomey-Calavi, Benin; 2. Department of Pharmacies, Drugs and Diagnosis, Ministry of Health, Benin; 3. Laboratory of Biology and Molecular Typing in Microbiology, Department of Biology and Cell Biology, University of Abomey, Benin.

Corresponding author: Victorien Dougnon, e-mail: victorien.dougnon@gmail.com

Co-authors: YC: chabiyoss@yahoo.fr, HK: charleshornel@yahoo.fr, JA: agbankpejerrold@yahoo.fr, RS: sefounonrd@gmail.com, DA: alledir72@gmail.com, HB: bahosour@yahoo.fr, LB: laminesaid@yahoo.fr Received: 29-11-2019, Accepted: 17-01-2020, Published online: 18-03-2020
\end{abstract}

doi: www.doi.org/10.14202/IJOH.2020.34-40 How to cite this article: Dougnon V, Chabi Y, Koudokpon H, Agbankpe J, Sefounon R, Alle D, Bankole H, Baba-Moussa L (2020) Prescription of antibiotics as a source of emerging antibiotic resistance: Knowledge, attitudes, and practices of medical staff in the Dassa-Glazoué and Savalou-Bantè's health zones (Benin, West Africa), Int. J. One Health, 6(1): 34-40.

\begin{abstract}
Background and Aim: Antibiotics have been some great effective molecules against infections since their discovery. The excessive use and misuse of antibiotics have resulted in a selection of antibiotic-resistant strains. Among the reasons involved, the prescription of antibiotics can be important. The present study aimed to contribute to the reduction of antibiotic resistance due to the misuse of antibiotics.

Materials and Methods: A knowledge, attitude, and practice survey of health professionals from Savalou-Bante (230) and Dassa-Glazoué (100) health zones was performed about the prescription of antibiotics.

Results: About 53\% of respondents in the health zone of Savalou-Bantè were assistant nursing and only 3\% of them were specialized physicians. The other respondents were physicians (3\%), midwives (10\%), and nurses (31\%). Forty-five percent of the respondents were nurses and only $5 \%$ of them were specialized physicians in Savalou-Bantè. However, all these health professionals prescribe antibiotics. The first-line antibiotics prescribed were penicillins, cephalosporins, macrolides, aminoglycosides, and quinolones. These health professionals usually have no knowledge of the mechanism of action of these antibiotics. The antibiotics prescribed mostly were for ear, nose, and throat and upper respiratory infections (80\% in Dassa-Glazoué and 79\% in Savalou-Bantè). The most commonly used dosage form was tablets (58\%) in the health zone of Savalou-Bantè and the injectable form in the sanitary zone of Dassa-Glazoué.
\end{abstract}

Conclusion: It is important to implement a policy of rational use of antibiotics to reduce the excessive and misuse of antibiotics and prevent antibiotic resistance.

Keywords: antibiotics, health professionals, knowledge, prescription.

\section{Introduction}

Infectious diseases and their treatments are constantly evolving. New infectious agents are regularly discovered, mainly due to the evolution of identification techniques, in particular, through the development of molecular biology and mass spectrometry [1]. Changes in the epidemiology of infectious diseases are not always explainable, but the following factors undoubtedly play an important role: Changes in climate, ecology and lifestyles, vaccinations, and finally antibiotic use [1].

Antibiotics are used in animal health, agriculture, and human health $[2,3]$. Excessive use and misuse of antibiotics have long been identified as responsible for the

Copyright: Dougnon, et al. This article is an open access article distributed under the terms of the Creative Commons Attribution 4.0 International License (http://creativecommons.org/licenses/ by/4.0/), which permits unrestricted use, distribution, and reproduction in any medium, provided you give appropriate credit to the original author(s) and the source, provide a link to the Creative Commons license, and indicate if changes were made. The Creative Commons Public Domain Dedication waiver (http:// creativecommons.org/ publicdomain/zero/1.0/) applies to the data made available in this article, unless otherwise stated. loss of sensitivity of microorganisms to antibiotics [4]. This is a widespread phenomenon nowadays known as antibiotic resistance, which is a real public health problem affecting both developed and developing countries [2]. It is associated with high mortality and generates a significant socioeconomic burden $[2,5,6]$. The WHO, therefore, recommends a rational and judicious use of antibiotics, which includes requiring a prescription by a health professional of antibiotics [7].

The prescription of antibiotics requires a good diagnostic approach including the establishment of an etiological diagnosis either by isolation and identification of the infectious agent or by serological tests to establish contact with pathogen [8]. In low-resource countries, these diagnostic options are limited because, in general, there are very few health facilities and appropriate laboratories. When they exist, they are traditionally poorly equipped and only allow basic examinations such as microscopy [9]. With these conditions, most treatments are presumptive and based on literature data from developed countries that do not necessarily 
share the same microbial ecology and may, therefore, be poorly adapted. In view of this, rural areas in developing countries often do not have a specialist physician or a well-developed care protocol for prescribing antibiotics. This is the case of the Dassa-Glazoué and Savalou-Bantè health zones in the department of the hills in Benin, which do not have a microbiology department. How do these health workers prescribe antibiotics in this health zone? This is the research question that prompted us to reflect on the theme: Knowledge, attitudes, and practices of health professionals in the Dassa-Glazoué and Savalou-Bantè's health zones.

The present study aimed to contribute to the reduction of antibiotic resistance due to the misuse of antibiotics.

\section{Materials and Methods}

\section{Ethical approval and informed consent}

The participation in the survey was voluntary and anonymous. Informed consent was obtained from participants. The Benin National Ethical Committee for Health Research has reviewed and approved the study under the No.65/MS/DC/SGM/DRFMT/CNERS/SA.

\section{Study framework}

This prospective and descriptive cross-sectional study covered the health zones of Savalou-Bantè and Dassa-Glazoué located in Benin (Figure-1). The Dassa-Glazoué's health zone has 39 public health units, including 1 zone hospital, 18 health centers at the district level, and 20 remote and isolated maternity

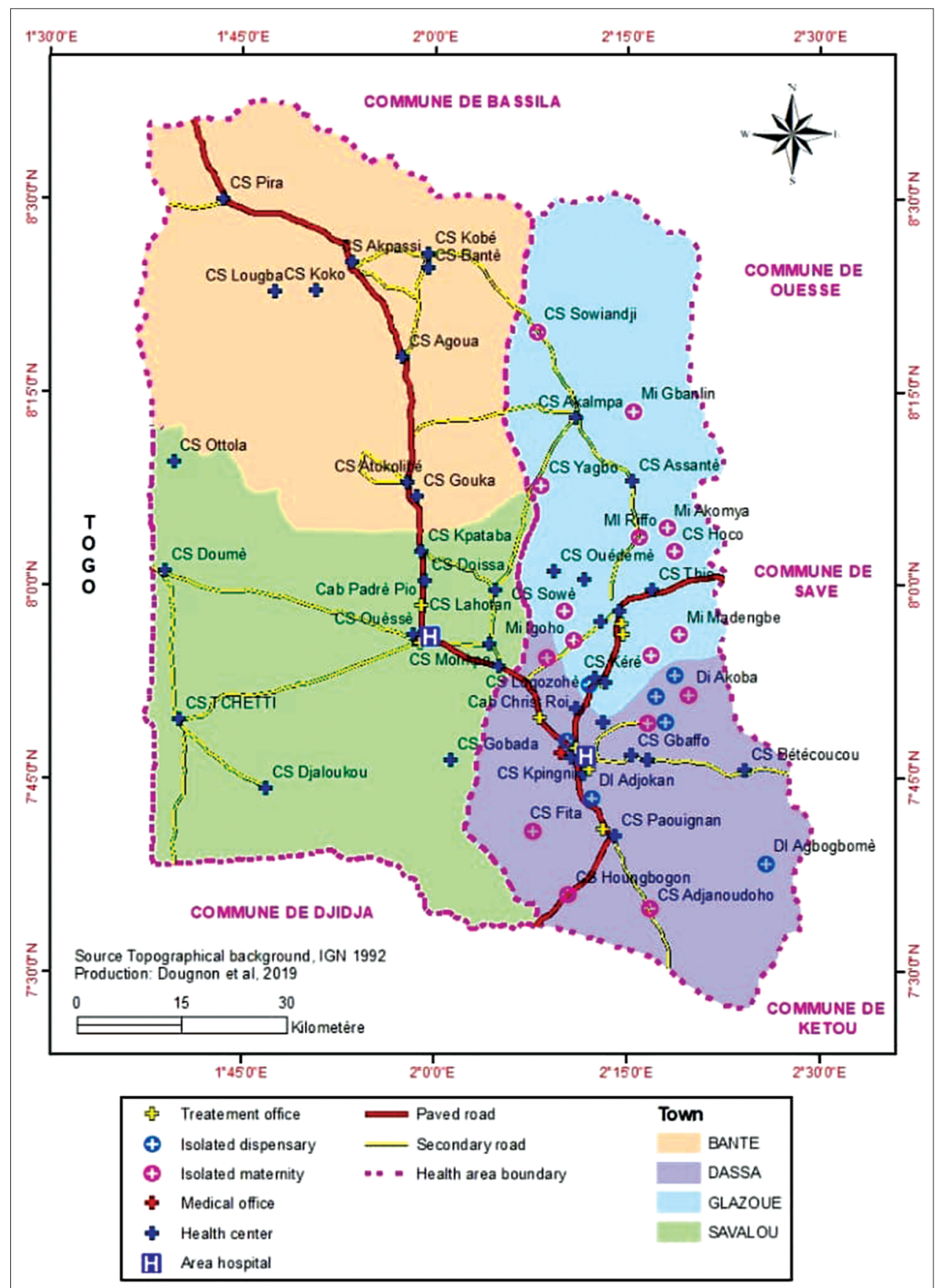

Figure-1: Geographical location of the Dassa-Glazoué and Savalou-Bantè health zones. 
units/dispensaries. The Savalou-Bantè's health zone has 30 health facilities, including 21 district health centers, 5 isolated maternity units, 3 remote and isolated dispensaries, and 1 zone hospital. The remote and isolated hospitals have not been included in this study.

\section{Study group (population and sampling)}

Our study population is, therefore, represented by all professional groups who prescribe antibiotics. Radiology technicians, laboratory technicians, and pharmacy clerks were excluded from this study since they do not prescribe antibiotics. Health-care assistants, nurses, state midwives, nurses/specialists midwives, general practitioners, and specialized physicians were then involved in 230 health professionals from the Savalou-Bantè health zone and 100 from the Dassa-Glazoué health zone were targeted.

\section{Knowledge, attitudes, and practices of health professionals}

A questionnaire was administrated to health professionals met in the health centers of the DassaGlazoué and Savalou-Bantè health zones. This was a knowledge, attitude, and practice survey with a direct interview system to collect information from the staff. The requested information were related to the sociodemographic data about each respondent (socioprofessional category), use of the various protocols, the control of the treatment (therapeutic failures, respect duration of the treatment) knowledge of antibiotics, prescribed first-line antibiotic, dosage form and method of administration of prescribed antibiotics, knowledge about antibiotic resistance, etc.

\section{Statistical analysis}

The data obtained were entered into the Excel spreadsheet, which was used to calculate the percentages and to produce the tables and graphs.

\section{Results}

The study of the profile of the respondents showed that in the Dassa-Glazoué health zone, $45 \%$ of the respondents were nurses and only $5 \%$ of them were specialists' physicians (Figure-2). About 53\% of the respondents in the Savalou-Bantè health zone were health-care assistants and 3\% are specialists' physicians. The prescription of antibiotics follows a protocol in $75 \%$ of cases in the Dassa-Glazoué health zone and in $79 \%$ of cases in the Savalou-Bantè health zone. About $55 \%$ of the staff use a protocol based on bacteriological tests in the Dassa-Glazoué health zone against $37 \%$ in the Savalou-Bantè health zone. About $40 \%$ and $63 \%$ of the staff use a protocol for the dosage form (tablets or injection) in the Dassa-Glazoué and Savalou-Bantè health zones, respectively. For the dosage of antibiotics, $95 \%$ of the staff of the DassaGlazoué health zone use a protocol for $84 \%$ in the Savalou-Bantè health zone. Only $5 \%$ of the staff in the Dassa-Glazoué health zone require a consultation before the prescription of antibiotics and $10 \%$ for the
Savalou-Bantè health zone (Table-1). Respectively, $60 \%$ and $31 \%$ of the staff of the Dassa-Glazoué health zone and the Savalou-Bantè health zone admit having difficulties in prescribing antibiotics. However, $100 \%$ of the staff in the Dassa-Glazoué health zone and $89 \%$ in the Savalou-Bantè health zone respect the duration of the treatment. About $90 \%$ of the staff of Dassa-Glazoué health zone and $79 \%$ of the SavalouBantè health zone were aware that the nature of the bacteria can influence antibiotic therapy. However, $85 \%$ of the staff in the Dassa-Glazoue health zone and $79 \%$ in the Savalou-Bantè health zone admit to experiencing therapeutic failures (Table-2). The treatment failures were caused by inappropriate antibiotic selection, antibiotic resistance, and non-compliance with treatment (Figure-3). The infections for which antibiotics were most prescribed were ear, nose, and throat (ENT) and upper respiratory infections, lower

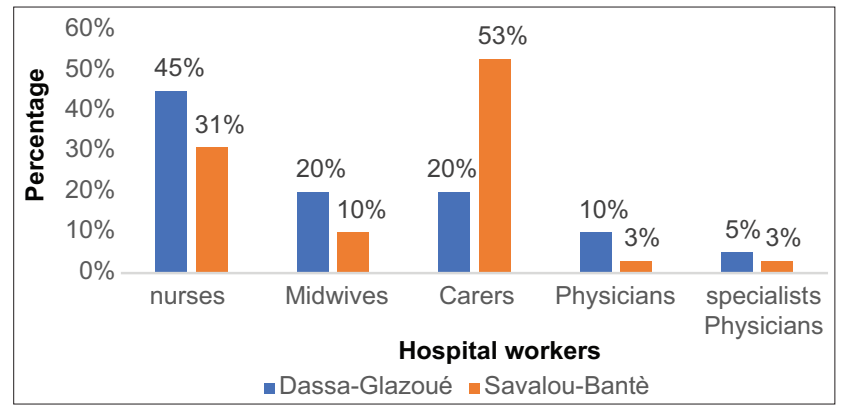

Figure-2: Distribution of respondents by hospital workers professions.

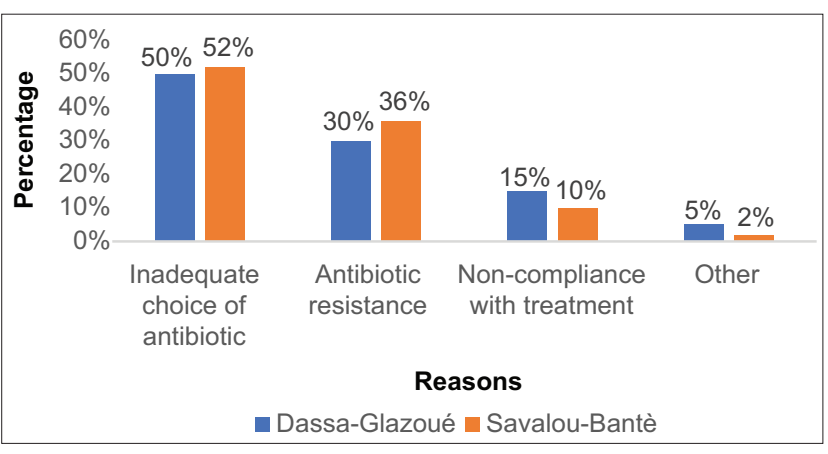

Figure-3: Causes of therapeutic failures.

Table-1: Use of a protocol for prescribing antibiotics.

\begin{tabular}{|c|c|c|}
\hline \multirow{2}{*}{$\begin{array}{l}\text { Antibiotic prescription } \\
\text { variables }\end{array}$} & \multicolumn{2}{|c|}{ Hospitals } \\
\hline & $\begin{array}{l}\text { Dassa- } \\
\text { Glazoué (\%) }\end{array}$ & $\begin{array}{l}\text { Savalou- } \\
\text { Bantè }(\%)\end{array}$ \\
\hline Antibiotic protocol & $75(75)$ & $182(79)$ \\
\hline $\begin{array}{l}\text { Protocol based on } \\
\text { bacteriological tests }\end{array}$ & $55(55)$ & $82(37)$ \\
\hline $\begin{array}{l}\text { Protocol based on dosage } \\
\text { form }\end{array}$ & $40(40)$ & $145(63)$ \\
\hline Protocol for dosage & $95(95)$ & $193(84)$ \\
\hline $\begin{array}{l}\text { Consultation-based } \\
\text { protocol }\end{array}$ & $5(5)$ & $25(11)$ \\
\hline $\begin{array}{l}\text { Protocol based on advice } \\
\text { from an infectious disease } \\
\text { specialist }\end{array}$ & $10(10)$ & $23(10)$ \\
\hline
\end{tabular}


respiratory infections, digestive infections, and urogenital infections. The ones for which antibiotics are least prescribed are osteoarticular infections and eye infections (Figure-4). The most commonly prescribed first-line antibiotic families were penicillins, cephalosporins, quinolones, and aminosides. The least prescribed families of antibiotics were polymyxins, rifamycins, monobactams, and glycopeptides. Antibiotics from carbapenem family were more prescribed in the Savalou-Bantè health zone $(68 \%)$ and antibiotics from sulfonamides family were more prescribed in the Dassa-Glazoué health zone (Table-3). It should also

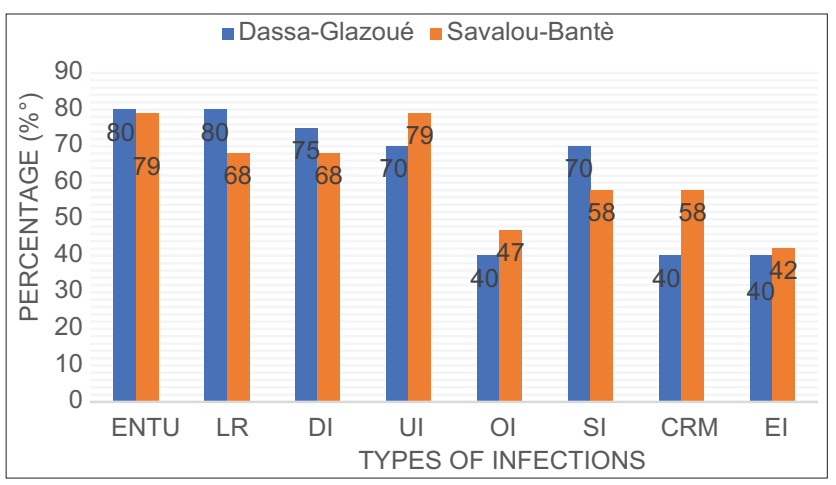

Figure-4: Infections frequently encountered for the prescription of antibiotics. ENTU = ENT and upper infections, $\mathrm{LR}=$ Lower respiratory infections, $\mathrm{DI}=$ Digestive infections, UI = Urogenital infections, OI = Osteoarticular infections, $\mathrm{SI}=$ Skin infections, $\mathrm{CRM}=$ Cerebro-meningeal infections, $\mathrm{EI}=$ Eyes infections.

Table-2: Difficulties in prescribing antibiotics.

\begin{tabular}{lcc}
\hline $\begin{array}{l}\text { Reasons } \\
\text { for prescription }\end{array}$ & \multicolumn{2}{c}{ Hospitals } \\
\cline { 2 - 3 } & $\begin{array}{c}\text { Dassa- } \\
\text { Glazoué (\%) }\end{array}$ & $\begin{array}{c}\text { Savalou- } \\
\text { Bantè (\%) }\end{array}$ \\
\hline $\begin{array}{l}\text { Difficulty in choosing } \\
\text { antibiotics }\end{array}$ & $60 / 100(60)$ & $71 / 230(31)$ \\
$\begin{array}{l}\text { Antibiotic treatment } \\
\text { based on the bacteria }\end{array}$ & $90 / 100(90)$ & $182 / 230(79)$ \\
$\begin{array}{l}\text { Respect of treatment } \\
\text { duration }\end{array}$ & $100 / 100(100)$ & $205 / 230(89)$ \\
\begin{tabular}{l} 
Therapeutic failure \\
\hline
\end{tabular} & $85 / 100(85)$ & $182 / 230(79)$ \\
\hline
\end{tabular}

be noted that the antibiotics most prescribed by health professionals were the most well-known to these professionals. Antibiotics in injectable form were the most commonly prescribed in the Dassa-Glazoué health zone (55\%) while in the Savalou-Bantè health zone, antibiotics in tablet were the most commonly used (58\%). Generic antibiotics were the most commonly prescribed in both centers. The health professionals surveyed justify this mainly by the unavailability of specialty drugs in the area (Table-4). Most of the agents surveyed have a good knowledge of antibiotic resistance. However, much less are aware of natural resistance to antibiotics. Most of them were aware that medical practice influences the emergence of antibiotics. Less than $50 \%$ of respondents received training on antibiotic prescribing and the concept of antibiotic resistance. These professionals recognize antibiotic resistance, especially through therapeutic failures. The antibiotic sensitivity test and the return of patients to the health center sometimes after treatment also allow them to detect antibiotic resistance. The large majority of the staff recognize that poor quality and inappropriate prescription of antibiotics are responsible for the development of antibiotic resistance (Table-5).

\section{Discussion}

The misprescribing of antibiotics in human therapeutics is one of the factors contributing to the misuse of antibiotics, which leads to the emergence of multiresistant germs. The present study conducted in the Savalou-Bantè and Dassa-Glazoue health zones revealed that health professionals include $53 \%$ of nurses' assistants and 3\% of specialists' physicians in the Savalou-Bantè health zone and $45 \%$ of nurses and $5 \%$ of specialists in the Dassa-Glazoue health zone. However, these health professionals all prescribe antibiotics. This situation is worrying because the prescription of antibiotics remains the responsibility of specialists [9]. The situation is all the more serious as caregivers prescribed antibiotics. Ouedraogo et al. [2] obtained similar results in Burkina Faso and indicated that the prescription of antibiotics by non-specialists is

Table-3: First-line and well-known antibiotic families.

\begin{tabular}{|c|c|c|c|c|}
\hline \multirow[t]{3}{*}{ Antibiotic families } & \multicolumn{4}{|c|}{ Hospitals } \\
\hline & \multicolumn{2}{|c|}{ Dassa-Glazoué } & \multicolumn{2}{|c|}{ Savalou-Bantè } \\
\hline & Using in firstline (\%) & Knowledge (\%) & Using in firstline (\%) & Knowledge (\%) \\
\hline Penicillins & $80 / 100(80)$ & $60 / 100(60)$ & $206 / 230(87)$ & $150 / 230(65)$ \\
\hline Cephalosporins & $55 / 100(55)$ & $55 / 100(55)$ & $156 / 230(68)$ & 38 \\
\hline Carbapenem & $15 / 100(15)$ & $10 / 100(10)$ & $156 / 230(68)$ & 24 \\
\hline Monobactams & $10 / 100(10)$ & $5 / 100(5)$ & $37 / 230(16)$ & $87 / 230(10)$ \\
\hline Quinolones & $20 / 100(20)$ & $20 / 100(20)$ & $97 / 230(42)$ & $62 / 230(27)$ \\
\hline Aminoglycosides & $20 / 100(20)$ & $15 / 100(15)$ & $108 / 230(47)$ & $92 / 230(40)$ \\
\hline Macrolides and related & $25 / 100(25)$ & $15 / 100(15)$ & $131 / 230(57)$ & $46 / 230(20)$ \\
\hline Glycopeptides & $10 / 100(10)$ & $0 / 100(0)$ & $12 / 230(5)$ & $18 / 230(8)$ \\
\hline Sulfonamides & $50 / 100(50)$ & $40 / 100(40)$ & $23 / 230(10)$ & $25 / 230(11)$ \\
\hline Polymyxins & $0 / 100(0)$ & $5 / 100(5)$ & $5 / 230(2)$ & $0 / 230(0)$ \\
\hline Rifamycins & $0 / 100(0)$ & $10 / 100(10)$ & $35 / 230(15)$ & $25 / 230(11)$ \\
\hline Other & $5 / 100(5)$ & $10 / 100(10)$ & $5 / 230(2)$ & $11 / 230(5)$ \\
\hline
\end{tabular}


Table-4: Characteristics of prescribed antibiotics.

\begin{tabular}{lcc}
\hline $\begin{array}{l}\text { Antibiotic attributes for } \\
\text { prescription }\end{array}$ & \multicolumn{2}{c}{ Hospitals } \\
\cline { 2 - 3 } & $\begin{array}{c}\text { Dassa- } \\
\text { Glazoué (\%) }\end{array}$ & $\begin{array}{c}\text { Savalou- } \\
\text { Bantè (\%) }\end{array}$ \\
\hline Dosage forms & $55 / 100(55)$ & $48 / 230(21)$ \\
$\quad$ Injectable & $25 / 100(25)$ & $133 / 230(58)$ \\
Tablets & $15 / 100(15)$ & $37 / 230(16)$ \\
Syrup & $5 / 100(5)$ & $11 / 230(5)$ \\
Suppository & & \\
S antibiotic specialties & $75 / 100(75)$ & $32 / 230(74)$ \\
$\quad$ Generics & $25 / 100(25)$ & $60 / 230(26)$ \\
Specialties & $15 / 100(15)$ & $25 / 230(26)$ \\
Perception about antibiotic specialties & \\
$\quad \begin{array}{l}\text { Poor quality of generics } \\
\text { Unavailability of specialty }\end{array}$ & $30 / 100(30)$ & $110 / 230(48)$ \\
drugs & & \\
Other & $55 / 100(55)$ & $60 / 230(26)$ \\
\hline
\end{tabular}

Table-5: Knowledge of antibiotic resistance.

\begin{tabular}{|c|c|c|}
\hline \multirow{2}{*}{$\begin{array}{l}\text { Knowledge based on } \\
\text { resistance }\end{array}$} & \multicolumn{2}{|c|}{ Hospitals } \\
\hline & $\begin{array}{l}\text { Dassa- } \\
\text { Glazoué (\%) }\end{array}$ & $\begin{array}{l}\text { Savalou- } \\
\text { Bantè }(\%)\end{array}$ \\
\hline \multicolumn{3}{|l|}{ General knowledge } \\
\hline Antibiotic resistance & $70 / 100(70)$ & $193 / 230(84)$ \\
\hline $\begin{array}{l}\text { Natural resistance to } \\
\text { antibiotics }\end{array}$ & $40 / 100(40)$ & $74 / 230(32)$ \\
\hline $\begin{array}{l}\text { Influence of medical } \\
\text { practice of resistance }\end{array}$ & $65 / 100(65)$ & $79 / 230(79)$ \\
\hline Training & $50 / 100(50)$ & $108 / 230(47)$ \\
\hline \multicolumn{3}{|c|}{ Antibiotic resistance detection } \\
\hline Treatment failed & $70 / 100(70)$ & 79 \\
\hline Antibiogram & $40 / 100(40)$ & 25 \\
\hline $\begin{array}{l}\text { Patient return to } \\
\text { hospital }\end{array}$ & $50 / 100(50)$ & 63 \\
\hline \multicolumn{3}{|c|}{$\begin{array}{l}\text { Knowledge of health professionals about the factors } \\
\text { responsible for the development of antibiotic resistance }\end{array}$} \\
\hline $\begin{array}{l}\text { Inappropriate } \\
\text { prescription }\end{array}$ & $75 / 100(75)$ & $193 / 230(84)$ \\
\hline Misuse & 70/100 (70) & $181 / 230(79)$ \\
\hline $\begin{array}{l}\text { Poor quality of } \\
\text { antibiogram }\end{array}$ & $30 / 100(30)$ & $12 / 230(5)$ \\
\hline $\begin{array}{l}\text { Non-compliance of } \\
\text { the treatment }\end{array}$ & $35 / 100(35)$ & $48 / 230(21)$ \\
\hline
\end{tabular}

at the origin of the emergence of antibiotic resistance. Health professionals use an antibiotic therapy protocol for the prescription of antibiotics. However, this protocol does not often take into account the results of a bacteriological examination (63\%), but it is well known that the same bacterial species do not necessarily mean the same treatments and that the same signs and symptoms do not necessarily converge toward the same infection [10]. These professionals do not use a protocol for the galenic form, but follow a protocol for the dosage. Indeed, the prescription of antibiotics requires a good diagnostic approach including the establishment of an etiological diagnosis either by isolation and identification of the infectious agent or by serological tests to establish contact with pathogen [11].

Furthermore, many medical treatments involve presumptive treatment, based on data from the literature in developed countries that do not necessarily share the same microbial ecology and may, therefore, be poorly adapted [2]. It is, therefore, important to develop local antibiotic therapy protocols for the most common diseases in a multidisciplinary setting, taking into account local reality of resistance to antibiotics [12].

The study of the infections that lead these professionals to prescribe antibiotics shows that ENT and upper respiratory infections (79\%), lower respiratory infections, digestive infections, and urogenital infections are the most affected. It is a common infection with many germs involved and, therefore, requires a bacteriological examination before the prescription. Tablets are the most prescribed as antibiotics (58\%) in the Savalou-Bantè health zone. This makes it easier to acquire, self-medicate for subsequent infections and makes it impossible for the health professional to monitor the effectiveness of antibiotic use. Injectable forms use under the supervision of a health professional will allow better to control the use of antibiotics at the appropriate times. Furthermore, not all antibiotics are available in injectable forms [13].

The first-line prescribed antibiotics are penicillins, cephalosporins, macrolides, aminosides, and quinolones. Health workers do not have great knowledge about these antibiotics families and their mode of action. In the Savalou-Bantè health zone, there is a great use of carbapenem which is normally used in case of resistance to the third-generation cephalosporins. This observation explains the emergence of resistance through the production of BLSE and carbapenem observed in Benin [13-16]. It is also well known that the use of third-generation cephalosporins is responsible for the slight reduction in carbapenem resistance [17].

The most prescribed antibiotics are generics. This is due to the modest conditions in rural areas where specialty drugs are often not available. The same observations were made by García et al. [18], Fathi et al. [19], and Thriemer et al. [20]. However, many health professionals do not trust these generic drugs. This worrying fact is likely to affect the promotion of drugs in hospitals to allow patients to have better access to drugs, especially for those with low socioeconomic status.

These agents are still aware of the phenomenon of antibiotic resistance acquired even if natural resistance is poorly known. This explains the many cases of therapeutic failure reported. About $57 \%$ of these professionals recognize up that inappropriate antibiotic selection is responsible for therapeutic failures. About $79 \%$ also recognized that medical practice is responsible for antimicrobial resistance. As in this study, other studies highlighted the good knowledge of health professionals about antibiotic resistance and the role of medical practice in the emergence of antibiotic resistance. They, therefore, argue that understanding practitioners' knowledge and perceptions of antibiotics use and resistance could increase the effectiveness of interventions to improve the quality of antibiotic therapy in hospitals [12,21]. However, in 
our study, about $50 \%$ of these agents have received training neither in the prescription of antibiotics nor on their consequences.

It is, therefore, more than important that measures be implemented to limit the inappropriate prescription of antibiotics. These measures must also include staff training on antibiotic prescribing and raising awareness among these health professionals about the consequences of inappropriate antibiotic prescribing. Furthermore, the introduction of computer systems for monitoring antibiotic resistance and prescription control would be an important support for reducing antibiotic resistance [22].

\section{Conclusion}

The rational use of antibiotics is a guarantee of good efficacy of antibiotics. The present study focused on the knowledge and practices of health-care professionals on the prescription of antibiotics, showed that the majority of antibiotics are prescribed by unqualified personnel who do not have a great deal of knowledge of antibiotics and on the consequence of their misuse. It is, therefore important that measures should be taken to monitor the prescription of antibiotics in the Savalou-Bantè health zone in particular and in Benin in general.

\section{Authors' Contributions}

VD, YC, HK, JA, HB, and LB wrote the protocol, planned the study, and supervised the work. RS and DA processed the samples under the supervision of VD and HK. All the authors reviewed the manuscript.

\section{Acknowledgments}

This study was self-funded. The authors thank the authorities from the health zones for permission and the University of Abomey-Calavi for the facilities offered.

\section{Competing Interests} work.

There are no competing interests related to this

\section{Publisher's Note}

Veterinary World (Publisher of International Journal of One Health) remains neutral with regard to jurisdictional claims in published map and institutional affiliation.

\section{References}

1. Cohen, K.A., Abeel, T., Manson McGuire, A., Desjardins, C.A., Munsamy, V., Shea, T.P., Walker, B.J., Bantubani, N., Almeida, D.V., Alvarado, L., Chapman, S.B., Mvelase, N.R., Duffy, E.Y., Fitzgerald, M.G., Govender, P., Gujja, S., Hamilton, S., Howarth, C., Larimer, J.D., Maharaj, K., Pearson, M.D., Priest, M.E., Zeng, Q., Padayatchi, N., Grosset, J., Young, S.K., Wortman, J., Mlisana, K.P., O’Donnell, M.R., Birren, B.W., Bishai, W.R., Pym, A.S. and Earl, A.M. (2015) Evolution of extensively drug-resistant tuberculosis over four decades: Whole genome sequencing and dating analysis of mycobacterium tuberculosis isolates from KwaZulu-Natal. PLoS Med., 12(9): e1001880.

2. Ouedraogo, A., Pierre Jean, H., Banuls, A., Ouédraogo, R. and Godreuil, S. (2017) Émergence et diffusion de la résistance aux antibiotiques en Afrique de l'Ouest: facteurs favorisants et évaluation de la menace emergence and spread of antibioticresistance in West Africa : Contributingfactors and threatassessment. Med. Sante Trop., 27(2): 147-154.

3. OMS. (2016) Résistance Aux Antimicrobiens. OrganMond la Santé. Aide-mémoi. Available from: http:/www.who.int/ mediacentre/factsheets/fs 194/fr. Retrieved on 22-07-2017.

4. Davies, J. and Davies, D. (2010) Origins and evolution of antibiotic resistance. Microbiol. Mol. Biol. Rev., 74(3): 417-433.

5. Naylor, N.R., Uchegbua, I., Chatterjeea, A. and Robothamc, J.V. (2017) Gambling with antibiotics: A novel approach to exploring antibiotic consumption decision-making? Public Health., 151: 146-148. Available from: https://www.spiral.imperial.ac.uk:8443/bitstream/10044/1/50082/2/phsc.pdf. Retrieved on 29-06-2019.

6. Naylor, N.R., Atun, R., Zhu, N., Kulasabanathan, K., Silva, S., Chatterjee, A., Knight, G.M. and Robotham, J.V. (2018) Estimating the burden of antimicrobial resistance: A systematic literature review. Antimicrob. Resist. Infect. Control, 7(58): 1-17.

7. OMS. (2016) Plan D'action Mondial Pour Combattre la Résistance Aux Antimicrobiens. Genève, Suisse. Available from: http://www.apps.who.int/iris/bitstream/10665/24954 8/1/9789242509762-fre.pdf. Retrieved on 17-10-2017.

8. Okeke, I.N., Laxminarayan, R., Bhutta, Z.A., Duse, A.G., Jenkins, P., O'Brien, T.F., Pablos-Mendez, A. and Klugman, K.P. (2005) Antimicrobial resistance in developing countries. Part I: Recent trends and current status. Lancet Infect. Dis., 5(8): 481-493.

9. Koudokpon, H. (2018) Etude de Quelques Bactéries Résistantes Aux Bêtalactamines Isolées D'infections Urogénitales: Caractérisation Moléculaire et Sensibilité Aux Extraits de Trois Plantes de la Pharmacopée Béninoise. University of Abomey-Calavi, Benin.

10. Chaussade, H., Sunder, S., Bernard, L., Coloby, P., Guy, L., Karsenty, G., Bastide, C. and Bruyère, F. (2013) Antibiotic treatments in urology. Prog. Urol., 23(15): 1327-1341.

11. Okeke, I.N., Laxminarayan, R., Bhutta, Z.A., Duse, A.G., Jenkins, P., O'Brien, T.F., Pablos-Mendez, A. and Klugman, K.P. (2005) Antimicrobial resistance in developing countries. Part I: Recent trends and current status. Lancet Infect. Dis., 5(8): 481-493.

12. Didouh, M. (2014) Evaluation de l'Implantation des Directives des Médicaments, Cas de l'Hôpital Mohamed V de l'Ecole Nationale de Santé Publique, Mémoire de fin d'Etudes, Maroc.

13. AFSSAPS. (2011) Mise au Point sur le bon Usage des Aminosides Administrés par Voie Injectable: Gentamicine, Tobramycine, Nétilmicine, Amikacine. Agence Française Sécurité Sanit des Prod Santé. p10. Available from: https:// ansm.sante.fr/var/ansm_site/storage/original/application/ f64613ed667c09bcb015026fa39e70a2.pdf. Retrieved on 20-02-2020.

14. Koudokpon, H., Dougnon, V., Azehoun, P.E., Kissira1, I., Hadjadj, L., Fanou, V., Loko, F., Bankole, H., Seydina, M.D. and Rolain, J.M. (2018) First report of carbapenemase producing gram negative bacteria in republic first report of carbapenemase producing gram negative bacteria in republic of Benin: Pseudomonas aeruginosa vim-2 new ST. Int. J. Biosci., 13(4): 437-443.

15. Koudokpon, H., Dougnon, V., Hadjadj, L., Kissira, I., Fanou, B., Loko, F., Honore, S.B., Seydina, D. and JeanMarc, R. (2018) First sequence analysis of genes mediating extended-spectrum beta-lactamase (ESBL) bla-TEM, SHV- and CTX-M production in isolates of enterobacteriaceae in Southern Benin. Int. J. Infect., 5(4): e83194.

16. Anago, E., Ayi-Fanou, L., Akpovi, C.D., Hounkpe, W.B., 
Agassounon-Djikpo, T.M., Bankole, H.S. and Sanni, A. (2015) Antibiotic resistance and genotype of beta-lactamase producing Escherichia coli in nosocomial infections in Cotonou, Benin. Ann. Clin. Microbiol. Antimicrob., 14(5): 1-6.

17. Muller, A., Bertrand, X., Rogues, A.M., Péfau, M., Alfandari, S., Gauzit, R., Dumartin, C., Gbaguidi-Haore, H. and ATB-RAISIN Network Steering Committee. (2018) Higher third-generation cephalosporin prescription proportion is associated with lower probability of reducing carbapenem use: A nationwide retrospective study. Antimicrob. Resist. Infect. Control., 7(2): 1-10.

18. García, C., Llamocca, L.P., García, K., Jiménez, A., Samalvides, F., Gotuzzo, E. and Jacobs, J. (2011) Knowledge, attitudes and practice survey about antimicrobial resistance and prescribing among physicians in a hospital setting in Lima, Peru. BMC Clin. Pharmacol., 11(18): 18.

19. Fathi, I., Sameh, O., Abu-Ollo, M., Naguib, A., SWR., Ghoneim, D., Elhabashi, S., Taha A., Ibrahim, Y., Radwan,
R., Nada, M. and Ramadan, M. (2017) Knowledge, attitudes, and beliefs regarding antimicrobial therapy and resistance among physicians in Alexandria University teaching hospitals and the associated prescription habits. Microb. Drug Resist., 23(1): 71-78.

20. Thriemer, K., Katuala, Y., Batoko, B., Alworonga, J.P., Devlieger, H., Van Geet, C., Ngbonda, D. and Jacobs, J. (2013) Antibiotic prescribing in DR Congo: A knowledge, attitude and practice survey among medical doctors and students. PLoS One, 8(2): e55495.

21. CDC. (2013) Antibiotic Antimicrobial Resistance. Available from: https://www.cdc.gov/drugresistance. Retrieved on 24-11-2019.

22. Muller, A., Patry, I., Talon, D., Cornette, C., LopezLozano, J.M., Plésiat, P. and Bertranda, X. (2006) Mise en place d'un outil informatisé de surveillance de la résistance bactérienne et de la consommation antibiotique dans un centre hospitalier universitaire. Pathol Biol., 54(2): 112-117.

$* * * * * * * *$ 